\begin{tabular}{|c|c|c|c|c|c|c|}
\hline \multirow{4}{*}{ Impact Factor: } & ISRA (India) & $=4.971$ & SIS (USA) & $=0.912$ & ICV (Poland) & $=6.630$ \\
\hline & ISI (Dubai, UAE & $=0.829$ & РИНЦ (Russia) & $=0.126$ & PIF (India) & $=1.940$ \\
\hline & GIF (Australia) & $=0.564$ & ESJI (KZ) & $=8.716$ & IBI (India) & $=4.260$ \\
\hline & JIF & $=1.500$ & SJIF (Morocco) & $=5.667$ & OAJI (USA) & $=0.350$ \\
\hline
\end{tabular}

\section{SOI: $1.1 /$ TAS $\quad$ DOI: $10.15863 /$ TAS \\ International Scientific Journal Theoretical \& Applied Science}

p-ISSN: 2308-4944 (print) e-ISSN: 2409-0085 (online)

Year: $2020 \quad$ Issue: 03 Volume: 83

Published: $09.03 .2020 \quad$ http://T-Science.org
QR - Issue

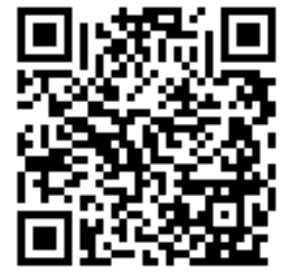

QR - Article

Nadira Makhkamovna Mamatkulova

Tashkent institute of architecture and civil engineering

Senior lecturer, Tashkent, Uzbekistan

\title{
STRATEGICS FOR IMPROVING THE COMPETITIVENESS OF INNOVATIVE MARKETING IN INDUSTRY ENTERPRISES
}

\footnotetext{
Abstract: In this article, you will see the relevance of developing industrial marketing enterprises based on innovative marketing strategies and classify innovative marketing strategies aimed at managing industrial activities, accelerating production processes and enhancing the competitiveness of industrial enterprises.

Key words: Industry, marketing, innovation marketing, economics, competition, innovation, product innovation, technological innovation, gaming marketing, marketing evangelism, storytelling, market mapping, fraud.

Language: English

Citation: Mamatkulova, N. M. (2020). Strategics for improving the competitiveness of innovative marketing in industry enterprises. ISJ Theoretical \& Applied Science, 03 (83), 15-17.

Soi: http://s-o-i.org/1.1/TAS-03-83-4 Doi: crossef https://dx.doi.org/10.15863/TAS.2020.03.83.4

Scopus ASCC: 1405.
}

\section{Introduction}

Gaining a high market share is a key factor for innovative development in countries around the world. Innovative developments in the world have increased by $7.8 \%$ over the past five years, and innovation costs account for $2.1 \%$ of global GDP [1].

Strategy of actions for development of the Republic of Uzbekistan for 2017-2021 "further modernization and diversification of industry by transferring high-tech processing networks, first and foremost, to high-quality finished goods production based on deep processing of local raw materials." [2] has been identified as one of the key areas. Effective use of innovative marketing strategies in industrial enterprises plays an important role in the effective implementation of these tasks. The first research on marketing innovations was undertaken in 1960 by Theodore Levitt, showing its impact on the effectiveness of the enterprise. Regardless of marketing innovation, many businesses now focus on product and process innovation. In his research, $\mathrm{T}$. Levitt "seeks to create and maintain the effectiveness of enterprise management by introducing innovations into the production process, as well as by introducing new marketing systems, even though they are aware of new products" [3], argues that. In his view, marketing innovation is seen as a process that is ignored by businesses and occurs spontaneously or by accident.

It is now widely recognized that full economic efficiency alone cannot be achieved by focusing on product innovation [4].

In general, marketing innovation is one of the key issues in developing a multi-system approach that should be widely studied. It can be seen that these conceptual approaches determine the relevance of a comprehensive analysis of innovative marketing and its study as a separate area of marketing.

Uzbekistan's oil and gas, chemical, automotive, construction materials and pharmaceuticals, light and food industries are developing dynamically. The share of industry in the GDP has increased by more than $8.5 \%$ in $2005-2018$, with more than $25.0 \%$ in total investment in fixed assets and about $38 \%$ in the total number of employed in the economy. However, the impact of global competition on global markets dictates that all countries must effectively use innovation in the development of industrial markets. Therefore, effective introduction of marketing innovations in the development of industrial enterprises based on the national economy characteristics, assessment of its formation and development, comprehensive study of theoretical and methodological issues, development of innovative marketing activities in industrial enterprises, 


\begin{tabular}{|c|c|c|c|c|c|c|}
\hline \multirow{4}{*}{ Impact Factor: } & ISRA (India) & $=4.971$ & SIS (USA) & $=0.912$ & ICV (Poland) & $=6.630$ \\
\hline & ISI (Dubai, UAE & $=0.829$ & РИНЦ (Russia & $=0.126$ & PIF (India) & $=1.940$ \\
\hline & GIF (Australia) & $=0.564$ & ESJI (KZ) & $=8.716$ & IBI (India) & $=4.260$ \\
\hline & JIF & $=1.500$ & SJIF (Morocec & $=5.667$ & OAJI (USA) & $=0.350$ \\
\hline
\end{tabular}

identification of specifics, innovative marketing activities of industrial enterprises in the country. the development of mechanisms to improve the organizational and legal framework are available.

The diversity of consumer needs and new forms of competition that create and execute their own market strategies based on the principles of innovative marketing strategies for industrial enterprises will help the company grow unprecedented growth opportunities.

\section{Methods of research}

The introduction of marketing innovations in conjunction with product innovation is a key issue. Old methods are not effective enough to enter the market with new products. The use of old marketing techniques to enter the market with a new product does not provide sufficient volume of sales for the new product [5].

The development of an innovative marketing strategy may differ to different markets, for example:

$>$ The individual emotions of a particular consumer play a key role in making B2C (business-tocustomers - business for the consumer) market;

$>$ In the B2B (business-to-business) market, the buyer's choice is based on rational thinking. The following key features of marketing in the B2B market.

$>$ Influence of rational factors on consumer motivation the focus of attention;

$>$ Impact on individual motivation of employees (salary increase, promotion, positive evaluation by the management, achievement of certain employment achievements);

$>$ Step-by-step and multi-level procurement decisions acceptance after processes;

$>$ Extension of procurement processes for a certain period;

A number of targeted strategies for innovative development of industrial enterprises abroad have been implemented.

In recent years, marketing innovation has been a major factor in enhancing the competitiveness of industrial enterprises in countries around the world. The countries are investing heavily in the development of science and research to ensure longterm industry development. It can be seen that the national innovation system created in developed countries promotes high economic growth.

Innovative development of the industry means the intellectual potential of industrial enterprises, the creative potential of workers and employees, knowledge, all stages from product creation to consumer. Innovation in these areas is a key resource for the strategic development of an industrial enterprise. In today's conditions, the economy is competitive with an innovative, intellectually-based, skilled workforce, and a high-tech industry.
Various organizational and economic principles that promote innovative marketing strategies have been developed and implemented in foreign companies.

Large corporations and companies have extensive experience in the use and application of innovative marketing technologies in various fields.

Sub Way, a fast-food retailer in India, launched its DART strategy in selling sandwiches in 1956. The main approach of the DART strategy is that the consumer creates the product for himself, that is, the buyer is directly involved in the creation of the product.

DART operates on a system of communication, access, risk assessment and information transparency (communication, access, risk assessment, transparency). Prahalad and Ramaswamy [6] describe the DART strategy as a key way to create value for innovative marketing, using a customer-centered, open-to-consumer, customer-centric approach.

Gamification is an innovative marketing strategy as a gaming approach to consumer engagement, a technology that is effectively used by US businesses. Its main principle is to promote new products in the market effectively through different mobile games.

Marketing evangelism is independent of providing technical information, developing diverse teams and consumers by relying on competent experts and creating a feedback channel is an innovative marketing strategy used to increase the level of loyalty and utilization of company products. Marketing evangelism represents the process of building up a new market and increasing market opportunities by introducing a new consumer image to the minds of consumers. Storytelling is an innovative marketing technology that is actively used in developing brands, especially new ones. This technology is based on a holistic brand history. Its main purpose is marketing strategy to attract consumers through praise slogans that affect them. Leading companies provide the consumer with a variety of tools and distribute videos that tell them about their achievements.

The market map is a map for users and reflects the movements of groups, distributors, information channels, potential company products, and market participants.

Crowdsourcing is an innovative marketing strategy aimed at reducing the commercial risk of innovative products by engaging consumers in news creation and testing. Crowdsourcing (crowdsourcing, crowd - "public" and sourcing - "resource use") solving problems and creating new brands based on the creativity, experience and knowledge of ordinary people.

\section{Conclusion}

Consenquently, it is possible for industrial enterprises to use, among other things, strategies such as past marketing, guerilla marketing, 


\begin{tabular}{|c|c|c|c|c|c|c|}
\hline \multirow{4}{*}{ Impact Factor: } & ISRA (India) & $=4.971$ & SIS (USA) & $=0.912$ & ICV (Poland) & $=6.630$ \\
\hline & ISI (Dubai, UAE & $=0.829$ & РИНЦ (Russia) & $=0.126$ & PIF (India) & $=1.940$ \\
\hline & GIF (Australia) & $=0.564$ & ESJI (KZ) & $=8.716$ & IBI (India) & $=4.260$ \\
\hline & JIF & $=1.500$ & SJIF (Morocco) & $=5.667$ & OAJI (USA) & $=0.350$ \\
\hline
\end{tabular}

micromarketing, mega marketing, green marketing, internal marketing, which are now the dominant types of marketing as a result of their entry into the market.
It should be seen not only as a priority in global competition, but also as an important area of development for countries.

\section{References:}

1. (2017). Te Global Innovation Index 2017. Innovation Feeding the World. Retrieved from htps://www.globalinnovationindex.org/gii2017-report

2. (2017). Decree of the President of the Republic of Uzbekistan Shavkat Mirziyoev "On the strategy of further development of the Republic of Uzbekistan" February 7, 2017 - Collection of legislation of the Republic of Uzbekistan. 2017, Issue 6, Article 70.

3. Levitt, T. (1960). 'Growth and profits through planned marketing innovation', Journal of Marketing, Vol. April, pp. 1-8.

4. Lin, C. Y.-Y., \& Chen, M. Y.-C. (2007). 'Does innovation lead to performance? An empirical study of SMEs in Taiwan', Management Research News, Vol.30, No. 2, pp. 115-132.

5. Usmanova, D. (2018). Methodological aspects of formation of marketing innovations. "Business Expert". No.10 (130) 2018. htpp:// www.biznes-daily.uz/ru/birjaexpert/61591--

Methodological aspects of developing marketing innovation

6. Prahalad, C., \& Ramaswamy, V. (2006). The future of competition. Creating unique value with the consumer. Moscow: Olympus Business.

7. (n.d.). Retrieved from www.Taqi.uz

8. (n.d.). Retrieved from www.strategy.uz

9. (n.d.). Retrieved from www.President.uz

10. (n.d.). Retrieved from www.mininnovation.uz 